\title{
Sir Harry C Sinderson Pasha (1891-1974): physician, medical educator and royal confidant
}

\author{
AS Jawad \\ Professor and Consultant Rheumatologist, Rheumatology Department, Barts and the London NHS Trust, London, UK
}

\begin{abstract}
Following the end of the First World War, several British orientalists had a significant influence on politics and development in a number of Arab countries in the Middle East. These include familiar figures such as TE Lawrence in Hejaz, Jordan and Syria, Gertrude Bell in Iraq, Harry St John Philby (later Sheikh Abdullah) in Saudi Arabia and Sir John Glubb (Glubb Pasha) in Jordan. There are however other less well-known individuals, of whom Harry Sinderson Pasha is one. Sinderson was a physician who played a significant role in the development of health and medical education in modern Iraq after it was established by the British in 1920. He was personal physician to the Royal family of Iraq, a confidant to King Faisal I and then to the Prince Regent, and he played an important role in the politics of that period.
\end{abstract}

KEYWORDS Medical education, medical history, Iraq, HC Sinderson, Royal College of Medicine

\author{
Correspondence to AS Jawad \\ Rheumatology Department, \\ Barts Health NHS Trust, \\ Whitechapel, London \\ EI 4DG, UK \\ tel. $+44(0) 2082238408$ \\ e-mail \\ ali.jawad@bartshealth.nhs.uk
}

DECLARATIONS OF INTERESTS No conflicts of interest declared.

Harry Chapman Sinderson was born in Caistor, in the West Lindsey district of Lincolnshire in England, on 9 June I89I, the son of William Sinderson and Maude Sinderson (née Chapman) (Figure I). He received his medical education at Edinburgh University, where, during his undergraduate years, he distinguished himself in several outdoor sports, representing the University at association football (1909-14, [captain 1911-12]) and at cricket (1913-14). He graduated MB, $\mathrm{ChB}$ in 19/4. During the First World War he served as Medical Officer Commanding on the hospital ships Stad Antwerpen and Wandilla, with the rank of Captain, but held the temporary rank of Major in the Special Reserve of the Royal Army Medical Corps (RAMC). Sinderson's first glimpse of Iraq was through field glasses from the bridge of the troopship HMT Minnetonka (Atlantic Transport Line) early in January

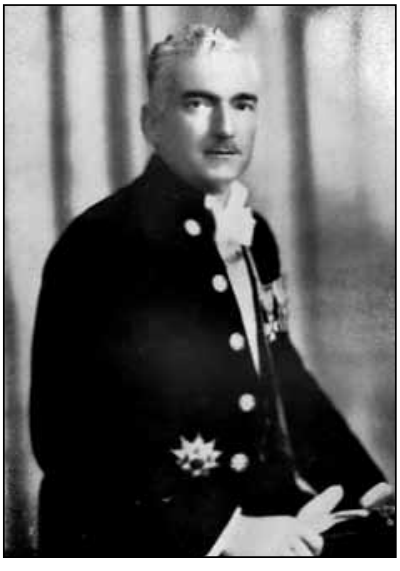

FIGURE I This picture of Sir Harry C Sinderson Pasha still hangs on the wall of the office of the Dean of the Medical College (University of Baghdad). (Courtesy of the present Dean of the Medical College).
1918. He landed at Fao in Iraq, where he recited words attributed to George Whitefield, the founder of the Calvinistic Methodists, 'that blessed word' Mesopotamia.'

\section{SINDBAD}

On board the troopship, bound for Basra from Salonika, was the entire staff and equipment of a 500-bedded general hospital, designated '65 British General Hospital $(\mathrm{BGH})$ '. One of the medical officers in the party was named Sanderson and both he and Sinderson were assigned to the same ship. To add further confusion, there was a Captain Sandison already on the staff. The Commanding Officer and Matron thought mistakes in identity were inevitable. The personal assistant to the Matron, a voluntary aid detachment (VAD), proposed that, as Sinderson's previous role had been that of a sailor, unofficial distinction was possible by giving him the pseudonym 'Sindbad'. This nickname stuck. The VAD, Miss Elsie MunGavin, became his wife two years later. ${ }^{2-4}$

\section{PRACTICING MEDICINE IN MESOPOTAMIA}

Soon after his arrival in Basra, Sinderson travelled by boat along the Tigris to Baghdad, a journey which took three days. They left the ship at Karadah, where the new hospital, a permanent building, was situated, around three miles south of the capital. Because the staff quarters were not yet completed, he stayed in a tent sufficiently roomy to accommodate two officers in ample comfort. However his tent companion developed sandfly fever and had to be transferred urgently to the officers' hospital in Baghdad. Within a fortnight, the Commanding Officer and nursing staff arrived and the hospital was opened. Sinderson's first post was as a medical registrar, but he was also assigned a ward in the medical division. ${ }^{5}$ 


\section{CIVILIAN HEALTH ADMINISTRATION}

By the time Sinderson was in Baghdad, at the end of the war, the British war administration had appointed Colonel WR Battye as Head of the Civilian Department of Health (Assistant Director of Medical Services [ADMS] [Civil]). His task was to coordinate the very few existing medical organisations into a modern national health service. Sinderson wrote: 'a formidable challenge, and Battye, a deeply religious man, convinced that divine purpose was the key to his appointment, set about his task with astonishing zeal. ${ }^{5}$ Sinderson was seconded for duty with him and became his assistant (Deputy ADMS [DADMS] [Civil]). This experience proved fascinating and rewarding for Sinderson. ${ }^{5}$ Battye proved to be a very successful recruiting officer and managed to delay the departure of a number of imminent specialists, persuading them to accept appointments in the new service.Among the first of these famous men were JJ (later Sir John) Conybeare of Guy's Hospital and Thomas (later Sir) Carey Evans, son-in-law of Lloyd George, Surgeon to the Viceroy of India (Lord Reading) and first Director of Hammersmith Hospital, then the seat of the British Postgraduate Medical School in London. ${ }^{5}$

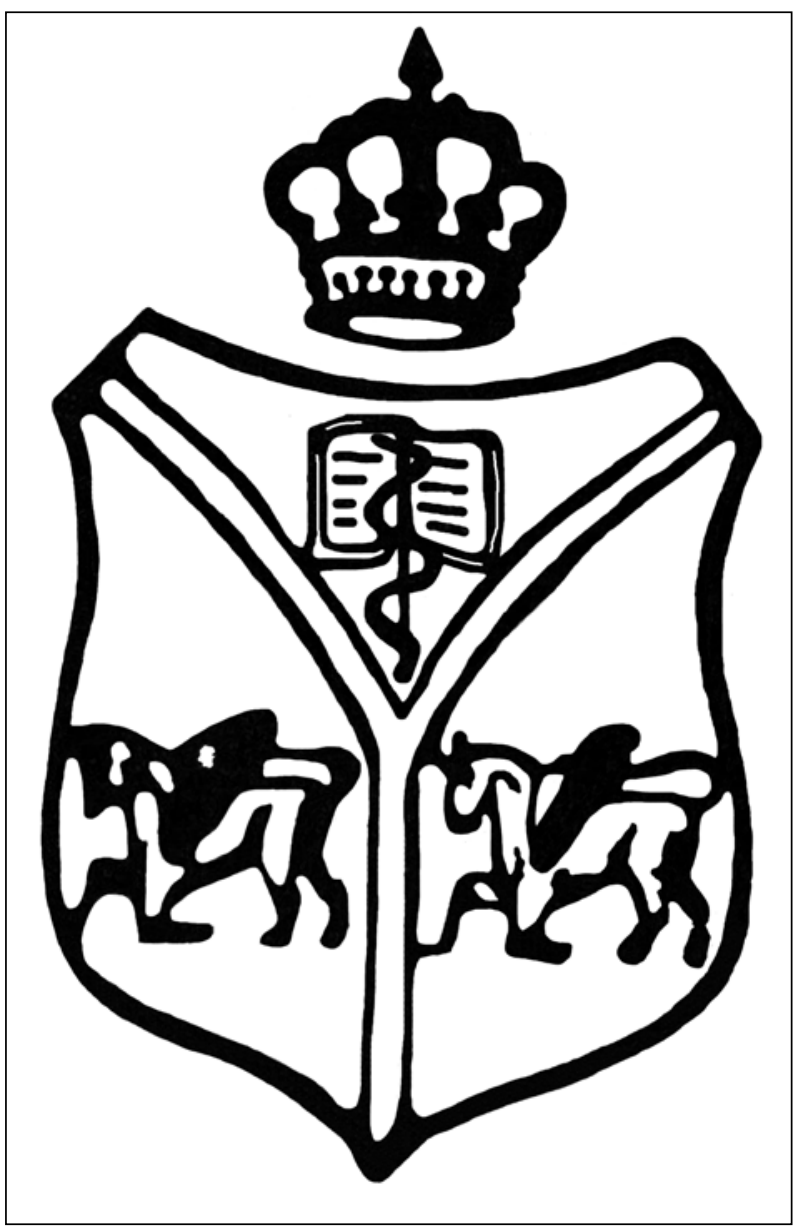

FIGURE 2 The shield of the Royal College of Medicine of Iraq (Courtesy of Mr Saad Al-Fattal).
In the summer of 1919, Sinderson was appointed civil surgeon to Hillah (a city in central Iraq on the Hillah branch of the Euphrates River, $100 \mathrm{~km}$ [62 miles] south of Baghdad). He began keeping records of helminthic infestations, which later became the basis of his MD thesis. ${ }^{6} \mathrm{He}$ also learned to speak Arabic. In June 1920, he married Elsie MunGavin, the VAD who had first named him Sindbad, and in September of that year he was transferred to Baghdad as civil staff surgeon, in charge of the Serai Nursing Home, a unit of the General Hospital. The following summer, he went back to the UK and enrolled on a University of London course to study tropical diseases; he passed with a diploma in tropical disease and health (DTM\&H). He also went to Edinburgh where he sat and passed the membership examination of the Royal College of Physicians of Edinburgh, becoming MRCPE. On his return to Iraq, he was the most highly qualified physician there. With his experience and qualifications, he was appointed in charge of the Civil Isolation Hospital during an outbreak of smallpox in Baghdad and later worked in the Railways Hospital. In 1926 he obtained his MD (Edinburgh) and was elected FRCPE. ${ }^{2,6,7}$ During his time in Iraq Sinderson continued to publish regularly in academic medical journals.

\section{THE ROYAL COLLEGE OF MEDICINE OF IRAQ}

The first medical school in modern Iraq, Baghdad Medical College, was established in 1927 with Harry Sinderson's help. He taught physiology and served as its first Dean and Professor of Medicine. The college adopted the Edinburgh curriculum, which reflected standard teaching curricula of the time in the UK and throughout the British Empire. ${ }^{8}$ Sinderson used wards 10 and $\mathrm{I} I$ in the Royal Hospital as the temporary site of the Medical College, with a small side room as his office. The first day of study was 29 November 1927. Soon after it opened, the Sindersons moved into a newly built house not far from the College. They named it 'AI Nakhl' (the Date Palms) on account of three date palm trees which, clustered together, dominating its attractive garden. It remained the Sindersons' home for the next 20 years. A new purpose-built building was commissioned for the Medical College and it was erected next to the Royal Hospital. King Faisal I, King of Iraq, was a great supporter of the medical college and offered his royal patronage. His Majesty officially performed the opening ceremony for the College on 4 April 1930; it became known as The Royal College of Medicine of Iraq. Elsie Sinderson designed the college badge: an escutcheon was adopted, depicting the three waterways of Iraq - the Tigris and the Euphrates merging with the Shatt al Arab to produce a $Y$-form. Within the arms of this $Y$ were represented a serpent and an open book, while below on either side of the stem there was an Assyrian bull. As a reminder of the royal patronage the crest also contained a crown (Figure 2). 
Students' fees were the equivalent of $£ 4$ per annum, payable in advance, and the students signed a contract to serve the Iraqi government for four years following graduation. Such a contract was vitally important to ensure a steady flow of qualified physicians, so badly needed to serve the country's population. Those candidates who did not wish to serve in the Iraqi Health Service paid fees the equivalent to $£ 40$ per annum. ${ }^{9}$

In 1932, the Conjoint Examining Board of the Royal Colleges of Physicians of London and Surgeons of England recognised the Royal College of Medicine of Iraq. This meant that the College graduates could undertake postgraduate training and work in Britain, and was hailed as a great achievement, boosting the morale of the teachers and the students in Baghdad. ${ }^{9}$ A School of Pharmacy, which had existed in Baghdad since 1922, had been closed due to a shortage of teaching staff and lack of financial support. It was reopened as a college in 1935, recruiting its candidates from secondary schools and becoming part of the Medical faculty.

Sinderson was associated with three other notable achievements in the establishment of formal medical training in Iraq. In 1932, he founded the Iraqi Red Crescent Society which was recognised by the International Federation in 1934; he also founded the Save the Children Fund in Iraq. ${ }^{9}$ In 1935 Sinderson established The Journal of the Faculty of Medicine, Baghdad, Iraq (later called The Journal of the Faculty of Medicine, Baghdad). The first five volumes appeared in Arabic only, but an English section was added in 194I. ${ }^{10}$

\section{THE ROYAL APPENDIX}

On 23 August 1921 Emir Faisal was crowned King Faisal I of Iraq, establishing a new Hashemite monarchy in what is now known as Iraq. He was the son of Ali bin Hussein, Sherif of Mecca and later King of Hejaz and former commander of the Arab forces that had helped the British during the First World War and entered Damascus at the culmination of the Arab Revolt. In August 1922, King Faisal developed acute abdominal pain, initially diagnosed as indigestion by Colonel Amin Ma'louf, the royal physician. Sinderson was asked to give a second opinion, and wrote 'The onset of the pain had been sudden, his tongue was furred, his temperature slightly raised, and his pulse a little quickened." He made a tentative diagnosis of acute appendicitis but Colonel Ma'louf was reluctant to agree and when Sinderson suggested consultation with a senior surgeon, the proposal was dismissed. But Faisal's condition deteriorated. Sinderson explained the situation to the King who agreed without hesitation to a further opinion. Miss Gertrude Bell (1868-1926), Oriental Secretary to the High Commissioner in Iraq and a close friend of the King, wrote on 8 September 1922 'I stayed till 6 o'clock when his doctors pay their official visit. Their appearance was straight out of comic opera. First his English physician and English surgeon, Dr Sinderson and Capt Braham - both salt of the earth; it's due to them that he is alive - then two completely incompetent Arab Army doctors, and behind them a cloud of witnesses whose presence remains unexplained. They were all there at the operation - every doctor in Baghdad seems to have been invited.' ${ }^{\prime 2}$ One of the rooms in the palace was converted into an operating theatre. The following day, Mr Noel Braham MS, FRCSEd (later professor of surgery) and Mr GSWoodman FRCSEd (later professor of surgery) successfully performed the appendicectomy with Harry Sinderson acting as the anaesthetist. The appendix was gangrenous. ${ }^{11,12}$ The following day Colonel Ma'louf resigned as the royal physician and left for Cairo two days later. His Majesty made an uneventful recovery. In April 1923, Harry Sinderson was appointed Physician to HM the King and the Royal family of Iraq. He was granted the Order of El Nahda of the Kingdom of the Hejaz in 1924. ${ }^{13}$

\section{ROYAL CONFIDANT}

In addition to being the royal physician, Harry Sinderson became a royal confidant, writing speeches for the King and helping him practice his public speaking in english. $\mathrm{He}$ accompanied the King when he met King Saud of Saudia Arabia in 1930 and on his visits to Persia in 1932 and Great Britain in June 1933. ${ }^{4}$ Sinderson was present at the meeting on 2I February 1930 between King Faisal and King Abdul Aziz Ibn Saud on board HMS Lupin, an event which was to prove extremely important because it helped settle some of the dynastic differences between the two families. Sinderson summarised the main points of the agreement in his autobiography. ${ }^{15}$

\section{TITLES AND DECORATIONS}

At the request of King Faisal, Sinderson examined the exiled King Hussein of the Hejaz in Cyprus in 1931. He then requested a transfer to Amman, the capital city of Jordan so that he could stay with King Hussein's son Abdullah. The request was granted by Sir Ronald Storrs, the governor of Cyprus. The exiled King Hussein summoned Sinderson to the presence of King Faisal and Emir Abdullah (Emir of Transjordan) and said:

'I am no longer a King and so cannot bestow a title on you. As yet Faisal does not confer appellations of rank, and so it has been left to Abdullah (Emir of Transjordan) to do so, and at my request, as head of the family, he has expressed his desire to bestow on you the title of Pasha and admit you to the Order of Istiqlal, that was once mine to give.'16

Sinderson proudly used the title of Pasha even after he was knighted (KBE) in 1946. He received many other honours: Order of the British Empire (OBE) in 1932, 
Member of the Royal Victorian Order (MVO) in 1933 and Companion of the Most Distinguished Order of Saint Michael and Saint George (CMG) 1942. He also received decorations from Sweden, Poland, Belgium and Iran. ${ }^{17-20}$

\section{DEATH OF KING FAISAL I}

King Faisal was a chain smoker and drank excessive amounts of strong coffee. In the summer of 1933 his general health deteriorated with weight loss and lack of appetite. He went to Berne, Switzerland on 2 September but died six days later of a heart attack. Sinderson, who was in London at the time, learned of the death from a newsflash when he and his wife were in a taxi not far from the embassy. They went at once to the Iraqi Legation and expressed their condolences to the ambassador. ${ }^{21}$ The King's physician in Berne, Dr Kocher, later sent the King's medical notes to Sinderson, who confirmed a diagnosis of coronary thrombosis.

\section{KING GHAZI}

After Faisal's death in 1933 Sinderson continued to be royal physician to his son, King Ghazi; the young King was not as fond of Sinderson as his father had been, though he did present his physician with a car, a Hupmobile, following the birth of his son (later King Faisal II) on 2 May 1935. Sinderson was unique in the expatriate community in having his own chauffeur, who was made the more distinctive by wearing western clothes and a chauffeur's cap. Sinderson would read his newspaper in the back seat. By contrast his British colleagues drove their own cars. ${ }^{4}$ In September 1934 Sinderson was replaced as Dean of the Medical College because pro-German support was growing stronger.

\section{ROYAL FATALITY}

Soon after midnight on 4 April 1939, King Ghazi died following a mysterious car crash (there is still debate over whether this was arranged by the British). Harry Sinderson was called to attend to the patient but his injuries were too extensive; the King died soon after Sinderson and Professor Braham arrived. Sinderson requested the senior aide to inform the Prime Minister of the situation. He also requested that $\mathrm{Mr}$ Saib Showket, the senior Iraqi surgeon, come to the Palace immediately. He was worried that in the absence of an Iraqi doctor, he and Professor Braham might be accused of being responsible for the King's death. Braham, Showket and Sinderson duly signed the death certificate, but these fears proved correct. The following morning a crowd surrounded the British Consulate in Mosul, North of Iraq and the British Consul was brutally murdered. ${ }^{22,23}$

\section{SINDERSON AND PRINCE REGENT}

On October 9, Emir Abdul Illah was appointed Crown Prince and Regent during King Faisal Il's minority following the death of his father King Ghazi. On the eve of the 194I Iraqi coup d'etat (also known as the Rashid Ali Al Gaylani coup or the Golden Square coup), Sinderson played a key role in helping the Prince Regent escape from Baghdad to the air base in Habbaniyah, north west of the city. From there he was flown to Basra and from there to Palestine via Amman. King Faisal II and other members of the Royal family were held in enforced residence under surveillance in Iraqi Kurdistan. The British Embassy and the American Legation were also under siege. A month later, the coup collapsed and on 2 June the Prince Regent and King Faisal II returned to Baghdad, and Rashid Ali fled the country. ${ }^{23}$

After the failure of the coup, Sinderson was reappointed Dean of the Medical College. Five Iraqi academics also served as deans, from September 1934 to June 1941. Sinderson's other official appointments at the time, apart from his duties at the Royal palace, included Chair of Medicine, Chief Physician to the Government of Iraq and Royal Hospital, Adviser and Inspector-General of Health Services, Ministry of Social Affairs and Health. In June 194I, he relinquished his commission as a Major in the British Army and was appointed Honorary Brigadier in the Iraqi Army by royal iradah (decree).

During the Second World War in 1943, Sinderson and his wife ran Noah's Ark, a welfare centre for Allied servicemen staffed by local women in Baghdad. Over a three-year period, they helped one million soldiers. ${ }^{2}$ Sinderson became a royal confidant to the Prince Regent, accompanying him and writing speeches for him on his official visits to Egypt and Western Desert battlefields in 1942, and going with him to Britain on his tour of wartime activities in November 1943 and to the USA in 1945. The party that visited Britain in November 1943 consisted of the Prince Regent, General Ismail Namiq, Chief of Staff of the Iraqi Army, Harry Sinderson and Lieutenant-Colonel Ubaid al-Mudhaifi, the aide-decamp to the Prince Regent. ${ }^{24}$ To travel with such distinguished company indicated the importance of Harry Sinderson to the Prince Regent (Figures 3 and 4).

In 1946, Sinderson submitted his resignation; his farewell party was held in the Regent Palace Hotel in Rasheed Street in Baghdad. It was attended by the Prime Minister, several cabinet ministers, senators, members of parliament, the faculty of the Royal College of Medicine and a large number of the graduates (including the first female graduate, Melek Ghannam). He was presented with a mini 'guffah' (a local rounded boat) made of gold. Sinderson left Iraq on 27 May 1946 having achieved his ambition of 500 doctors graduating from the Royal College of Medicine. In June 1946, King Faisal II and 
women from Iraq's Royal House travelled to England in the Turkish President's yacht Savarona, with Sinderson a member of the delegation. King Faisal II, Prince Abdul Illah and Nuri Pasha al-Said, the Prime Minister, all attended the Victory Parade in London. At the end of the visit, Sinderson remained in England.

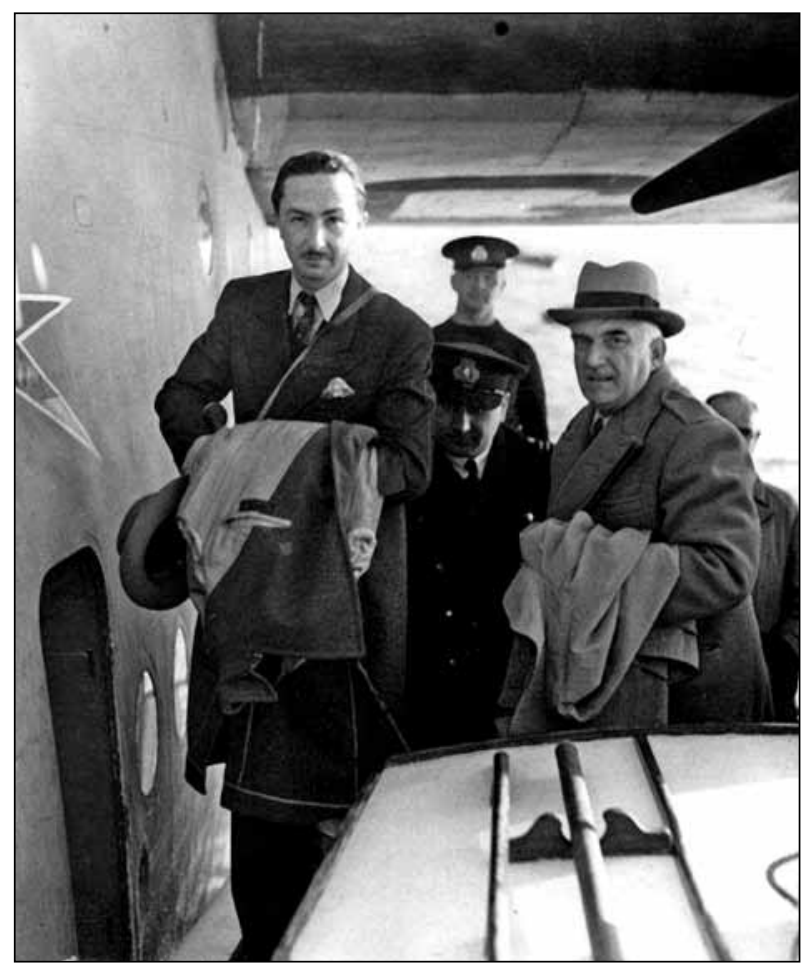

FIGURE 3 Prince Regent (left) and Harry Sinderson aboard a military transport during a visit to the USA in 1945 (Courtesy of Mr Saad Al-Fattal).

\section{KING FAISAL II}

Harry and Elsie Sinderson returned to Baghdad for the last time when King Faisal II attained the age of majority on 2 May 1953. They gave the young King a parchment with a representation of the King's family tree, a record of his ancestry. This parchment had been obtained by Sir Percy Cox, the British High Commissioner (1920-1923) and on his death was given to Sinderson by Lady Cox. King Faisal II was very pleased with the present and it became his most treasured possession." The King suffered from asthma and used to communicate with Sinderson by letter, referring to him as 'docky'. His last contact was when King Faisal II wrote to Sinderson on 25 June 1958, I9 days before he was killed in a military coup on 14 July $1958 .{ }^{25}$

\section{RETURN TO ENGLAND}

After his retirement from Iraq to his home in Sussex in England, Sinderson devoted his time and energy to working for local and national charities. He became Sussex county director for the St John Ambulance Association, and in May 1955 he was appointed member

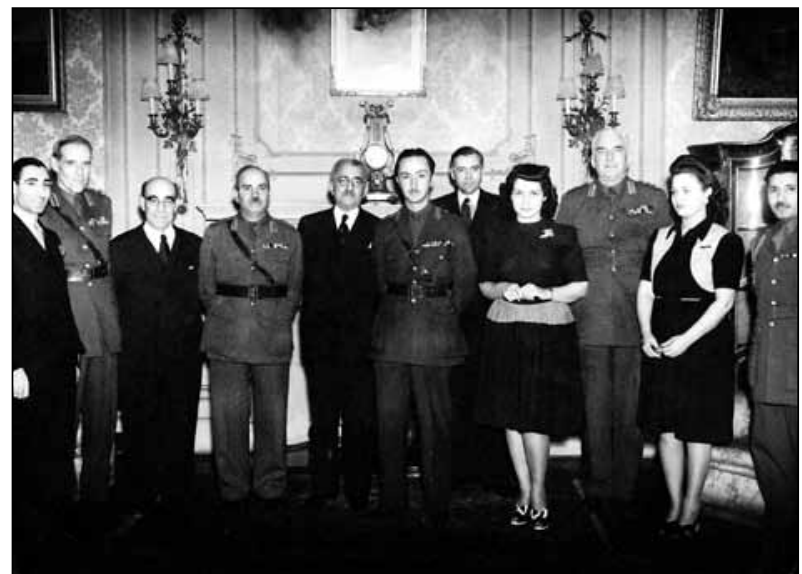

FIGURE 4 The Prince Regent party visiting the Iraqi Legation (embassy) in Britain in November 1943. The first from the right is Lieutenant-Colonel Ubaid al-Mudhaifi, $A D C$, second and fourth are the daughters of the Iraqi minister, third is Harry Sinderson in an Iraqi Brigadier uniform, sixth is Prince Regent, seventh is Jafar Pasha Al-Hayderi, Minister of the Iraqi Legation, ninth is General Ismail Namiq, Chief of Staff and eleventh is Colonel Sir Eric Crankshaw. (Courtesy of Mr Ahmed Al-Hayderi).

of the Food Hygiene Advisory Council by the Minister of Agriculture, Fisheries and Food. ${ }^{26}$ In 1956, the Queen sanctioned his appointment as Commander (Brother) to the Most Venerable Order of the Hospital of St John of Jerusalem, ${ }^{27}$ a royal order of chivalry with the worldwide mission of preventing and relieving sickness and injury and acting to enhance the health and wellbeing of people. He represented the Royal College of Physicians of Edinburgh on the Imperial Cancer Research Fund; he was also a vice-president of Brighton College, a member of the Royal Society of St George, the Fauna Preservation Society, the Marylebone Cricket Club (MCC) and Warden of Sackville College, Sussex. ${ }^{2} \mathrm{He}$ also lent his support to a number of local sporting and charitable associations, among them the East Grinstead Football Club and the Forest Row British Legion, of which he was president at the time of his death.

After the death in 1967 of his wife Elsie, a constant source of strength and comfort, he started writing his autobiography Ten Thousand and One Nights, which he dedicated to her. It was published in 1973 to good reviews. ${ }^{28}$ Najdat Fathi Safwat, an Iraqi diplomat and later journalist based in London at the time, wrote to Sinderson soon after his autobiography was published, congratulating him on his book and offering a few notes. Sinderson promptly rang Safwat to thank him and invited him for tea. ${ }^{29}$ On his arrival at Sinderson's home, Safwat noticed a small pond in the garden with a small Iraqi 'guffah' in the middle. Sinderson smiled and said he had enjoyed watching the guffahs moving along the Tigris River and had shipped this guffah to England to remind him of the happy days he spent in Iraq. Safwat commented that Sinderson was a shadow of the man he knew from the 1940s: frail, unsteady on his feet and slightly stooped, 
wearing glasses with thick lenses. He told Safwat that though he was pleased with the publicity his autobiography was receiving in the UK, he wished that it could be translated into Arabic. ${ }^{29} \mathrm{~A}$ few years later, Sinderson's book was indeed translated and more than one edition has since been published.

Sinderson died on 20 November 1974, at his home 'Little Steddings' in Forest Row, Sussex (which he bequeathed to the National Children's Home in memory of his two children, one of whom had been stillborn and the other who died soon after birth). His funeral service was held at St Swithun's Church, East Grinstead and a memorial service was held on 20 January 1975 at the Grand Priory Church of the Most Venerable Order of the Hospital of St John of Jerusalem, of which he was knight justice. ${ }^{30}$

Sir Harry Sinderson helped shape every medical institution in Iraq during the first 25 years of the existence of the modern state. By the time he left, 500 doctors had graduated from the medical school he founded. His professional qualities earned him the respect of the Iraqi Royal family, of politicians in Iraq, the Middle East and in Britain, as well as his colleagues and his students. He left the country he loved at the right time, before anti-British feeling in Iraq became prevalent. Sinderson's name will always occupy a special and honourable place in the land of Mesopotamia, the country he served so well.

\section{Acknowledgements}

I thank Mr Ahmed Al-Hayderi and Miss Tamara Al-Daghistani for providing me with Figure 2 (unpublished before) and for the very useful information. I also thank Professor MK Al-Janabi, the current Dean of the Medical College, University of Baghdad for giving written permission to publish the a photograph of Sir Harry Sinderson Pasha (Figure I). I also thank Mr Saad Al-Fattal, the Iraqi medical historian for correcting some historical data and giving permission to publish Figure 4 and the shield of the Royal Medial College of Iraq. I am also grateful to Mr Salman Al-Saffar for providing references in Arabic and Miss Ophelia Wynne for converting the images into high resolution.

\section{REFERENCES}

I Sinderson HC. Ten thousand and one nights: memories of Iraq's Sherifian Dynasty. London: Hodder \& Stoughton Ltd; I973. p. 25.

2 Obituary: Sir Harry Sinderson Pasha. Asian Affairs 1975; 6:235-6. http://dx.doi.org// 0.1080/03068377508729760

3 Sinderson HC. Ten thousand and one nights: memories of Iraq's Sherifian Dynasty. London: Hodder \& Stoughton Ltd; 1973. p. 19.

4 Isaacs H. Sir Harry Sinderson Pasha (189I-1974). British Society for Middle Eastern Studies. Bulletin 1975; 2:55-6.

5 Sinderson HC. Ten thousand and one nights: memories of Iraq's Sherifian Dynasty. London: Hodder \& Stoughton Ltd; 1973. p. 27-37.

6 Sinderson H. Some health problems of the Middle East. Journal of the Royal Central Asian Society 1947; 34: I31-43. http://dx.doi. org/10.1080/0306837470873/249

7 Sinderson HC. Ten thousand and one nights: memories of Iraq's Sherifian Dynasty. London: Hodder \& Stoughton Ltd; 1973. p. 46-57.

8 Al-Samarraie K. Talk of the eighties. vol 4. Baghdad: Ministry of Culture and Media; 1997. pp. 269-90. (Arabic).

9 Isaacs H. Britain's contribution to medicine and the teaching of medicine in Iraq. British Society for Middle Eastern Studies. Bulletin 1976; 3:20-8.

10 Wilson JVK. Gleanings from the Iraq medical journals. Journal of NearEastern Studies 1968;27:243-7.http://dx.doi.org/ / 0.1086/37/970

II Sinderson HC. Ten thousand and one nights: memories of Iraq's Sherifian Dynasty. London: Hodder \& Stoughton Ltd; 1973. Pp. 56-77.

12 Bell G. Letters 8/9//922 [Internet]. The Gertrude Bell Archive. Newcastle: Newcastle University; 1922 [cited 2013 Jan I5].Available from: http://www.gerty.ncl.ac.uk/letter_details.php?letter_id=577

13 Order of El-Nahda. The London Gazette. 1924 March 25.

14 News. The Times 1933 June 25.
I5 Shikara A. Faisal's ambitions of leadership in the fertile crescent: aspirations and constraints. In: Kelidar A, editor. The integration of modern Iraq. London: Croom Helm Ltd; 1979. p. 38.

16 Sinderson HC. Ten thousand and one nights: memories of Iraq's Sherifian Dynasty. London: Hodder \& Stoughton Ltd; 1973. p. 125.

17 Regular Army. Supplement to the London Gazette 1942 April 3. p. 1497.

18 Death announcements. The Times 1974 November 23.

19 Obituary: Harry Chapman Sinderson. Br Med J 1974; 4:598-600. http://dx.doi.org/I 0.I I 36/bmj.4.5944.598

20 Harry Chapman Sinderson. Lancet 1974; 2: 1403.

21 Sinderson HC. Ten thousand and one nights: memories of Iraq's Sherifian Dynasty. London: Hodder \& Stoughton Ltd; 1973. p. 153.

22 Sinderson HC. Ten thousand and one nights: memories of Iraq's Sherifian Dynasty. London: Hodder \& Stoughton Ltd; 1973. p. 156-72.

23 De Gaury G. Three kings in Baghdad: the tragedy of Iraq's monarchy. 2nd ed. London: IB Tauris; 2008. pp. I I0-35.

24 News. The Times 1943 November 17.

25 Sinderson HC. Ten thousand and one nights: memories of Iraq's Sherifian Dynasty. London: Hodder \& Stoughton Ltd; 1973.Appendix I.

26 Food Hygiene Advisory Council. Commons Sitting. Hansard 1955; 540: cl323.

27 Appointment as Commanders (Brothers). The London Gazette 1956 January 6. p. 142.

28 McRobert GR. Royal physician in Iraq. Br Med J 1974; I:332. http:// dx.doi.org/ I0. I 136/bmj. I.5903.332-b

29 Najdat Fathi Safwat. Notes and talks in history. Ist ed. Baghdad: Ashbilia Press; 1983. p. 195-204. (Arabic)

30 Obituary. Sir H Sinderson Pasha. The Times 1974 December 6. 